Review

\title{
Antimicrobial Peptides: Multifunctional Drugs for Different Applications
}

\author{
Lars-Ove Brandenburg ${ }^{1, *}$, Julika Merres ${ }^{1}$, Lea-Jessica Albrecht ${ }^{1}$, Deike Varoga ${ }^{2, \dagger}$ and \\ Thomas Pufe ${ }^{1, \dagger}$
}

1 Department of Anatomy and Cell Biology, RWTH Aachen University, D-52074 Aachen, Germany; E-Mails: amerres@ukaachen.de (J.M.); lalbrecht@ukaachen.de (L.-J.A.); tpufe@ukaachen.de (T.P.)

2 Department of Trauma Surgery, University Hospital Schleswig-Holstein, Campus Kiel, D-24105, Germany; E-Mail: deike.varoga@hotmail.com

* Author to whom correspondence should be addressed; E-Mail: 1brandenburg@ukaachen.de; Tel.: +49-241-808-9548; Fax: +49-241-808-2431.

$\dagger$ These authors contributed equally to this work.

Received: 25 December 2011; in revised form: 9 February 2012 / Accepted: 10 February 2012 / Published: 16 February 2012

\begin{abstract}
Antimicrobial peptides (APs) are an important part of the innate immune system in epithelial and non-epithelial surfaces. So far, many different antimicrobial peptides from various families have been discovered in non-vertebrates and vertebrates. They are characterized by antibiotic, antifungal and antiviral activities against a variety of microorganisms. In addition to their role as endogenous antimicrobials, APs participate in multiple aspects of immunity. They are involved in septic and non-septic inflammation, wound repair, angiogenesis, regulation of the adaptive immune system and in maintaining homeostasis. Due to those characteristics AP could play an important role in many practical applications. Limited therapeutic efficiency of current antimicrobial agents and the emerging resistance of pathogens require alternate antimicrobial drugs. The purpose of this review is to highlight recent literature on functions and mechanisms of APs. It also shows their current practical applications as peptide therapeutics and bioactive polymers and discusses the possibilities of future clinical developments.
\end{abstract}

Keywords: antimicrobial peptide; innate immunity; infection; therapeutics; inflammation 


\section{Introduction}

The term "Antimicrobial peptides" (APs) is used to describe a large number of small proteins that can kill or inhibit growth of various microorganisms They were first discovered in the late 1980's in the African clawed frog Xenopus laevis and were proven to provide a natural protection against infections [1,2]. This cationic peptide class, referred to as magainins, showed a broad spectrum of activities, including antifungal and antiparasitic activities. In the following decades a variety of different peptides, also called host defense peptides, were identified and isolated from many organisms, including plants, bacteria, fungi, insects and vertebrates. APs play an important role in the innate immune system displaying the first line of defense against infections [3]. Plants and nonvertebrates lack certain elements of the adaptive immune system, therefore APs provide the crucial defense mechanism [4]. In plants, the presence of APs prevents colonization of bacteria and fungi [5]. In mammals, APs are conserved and located primarily in epithelial and non-epithelial surfaces, where they maintain barrier function and prevent microbial invasions. APs were first isolated from phagocytic cells of the immune system, such as neutrophil granulocytes, but have also detected in mesenchymal tissue, such as articular cartilage, or in mucosal epithelial cells [6,7]. In the skin they are involved in maintaining the barrier functions of the keratinocytes [8], as well as also maintaining the blood brain barrier and the meninges of the brain $[9,10]$.

APs are characterized by their small size (12-50 amino acids), the arginine and lysine residues responsible for their positive charge and an amphipathic structure that enables them to interact with microbial membranes [11]. Based on primary and secondary structural differences, antimicrobial potentials and effects on host cells, APs can be divided into different families. Therefore, in mammals, three families have been described: defensins, cathelicidins and histatins (see Table 1; [12]). Please note that many more peptides have been identified in addition to these three main families, e.g., RNase 7, hepcidin or lactoferrin. A good overview of the existing APs is provided by the antimicrobial peptide database (APC) [13].

Defensins are widely expressed, show bactericidal, antifungal and antiviral activity and are enriched mainly in cells and tissues involved in host defense. Due to six conserved cysteins in the primary structure of defensins, the specific structure and function is determined by three disulfide bonds. According to the position of the cysteins, defensins have been classified as $\alpha-, \beta$ - and $\theta$-defensins. In mammals, high concentrations of defensins have been detected on the skin and mucosal surfaces. Additionally, they provide granular proteins in neutrophil granulocytes (circa 30\%) and in paneth cells of the small intestine [14]. However, related members of the defensin family have also been identified in plants (Arabidopsis thaliana) and non-vertebrates [3,5].

Cathelicidins are defined by a highly conserved N-terminal cathelin pro-domain and a structurally variable antimicrobial domain at the C-terminus. They have been identified in various species, with substantial interspecies variation in the number of different family members expressed. In rodents and humans one gene for cathelicidins is known, whereas other mammals, such as pigs, cattle and horses have several genes [15]. In humans, the cathelicidin gene encodes an inactive precursor protein (hCAP18) that is processed to release a 37 amino acid peptide with two leucine residues at the beginning (LL-37) of the C-terminus of the precursor protein [16]. The cathelicidins are produced by leukocytes, but recent studies have shown them to have a broad distribution including skin, epithelial 
and brain tissue [17-22]. The expression is hence not limited to lymphoid organs or leukocytes. Cathelicidins kill Gram-positive and Gram-negative bacteria [23]. Interestingly, they may show an antiparasitic activity against Trypanosoma cruzi [24]. Recent results have also shown cathelicidin-like peptides in plants [25], whereas in non-vertebrates, no representatives have been detected yet.

The third main family of APs in mammals, the histatins, includes various small, cationic, histidine-rich peptides. They are constitutively produced and secreted by the oral saliva gland such as the parotid, submandibular and sublingual glands [26]. They show a potent bactericidal and also fungicidal activity and therefore play an important role in maintaining oral health by limiting infections in the oral cavity [12]. Histatins have hitherto been isolated from humans and primates only [27].

The expression of APs is mediated mainly by the pattern recognition receptors (PRR), which recognize conserved pathogen-associated molecular structures, such as bacterial cell wall components, bacterial DNA or viral envelop proteins. For example, both Toll-like receptors and formyl peptide receptors are involved in AP expression [28,29].

Table 1. Main human AP families and their members.

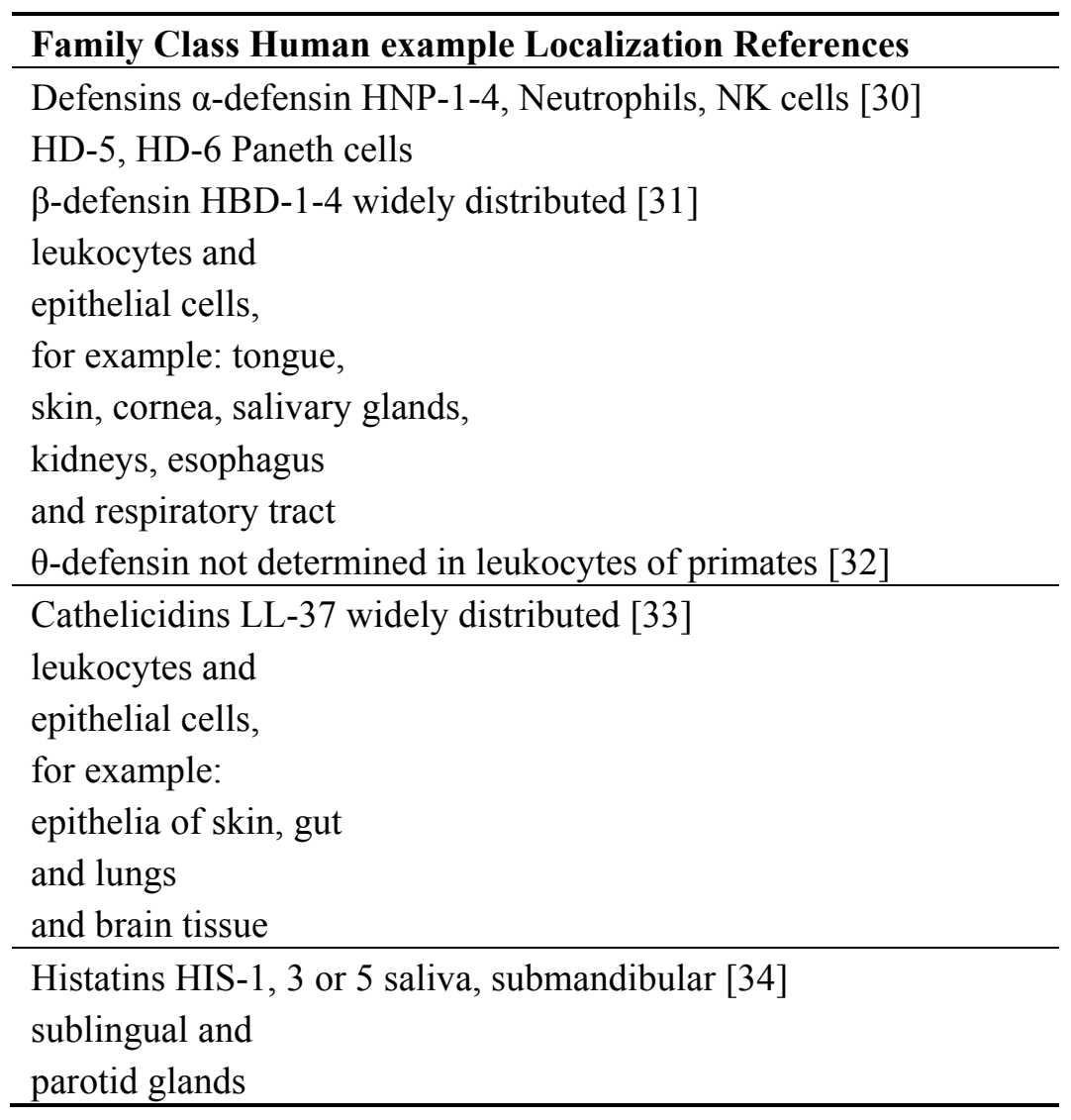

\section{Diversity of Functions}

\subsection{Antimicrobial Activity}

Antibacterial activity: APs show antimicrobial activity against a broad range of microorganisms including Gram-positive and -negative bacteria [35], and there are several hypotheses describing mechanism function. The initial contact between the AP and the microbe is electrostatic, because of 
the anionic bacterial surface. Firstly, the positively charged cationic peptides (APs) bind to the negatively charged cellular membrane components from the bacterial cell wall such as lipopolysaccharide. The amino acid composition, amphipathicity, cationic charge and size allow them to attach to and insert into membrane bilayers to form pores by 'barrel-stave', 'carpet' or 'toroidal-pore' mechanisms (see Figure 1; [36]). For the barrel-stave, the peptides aggregate and insert into the membrane bilayer in order to align the hydrophobic peptide regions with the lipid core region. The hydrophilic peptide regions form the inner core of the pore. For the toroidal, the peptides aggregate and induce the lipid monolayers to bend continuously through the pore so that the water core is lined by both the inserted peptides and the lipid head groups and for the carpet channel, the peptides disrupt the membrane by orienting parallel to the surface of the lipid bilayer and forming an extensive layer or carpet. This results in the formation of a transient channel, micellarization, dissolution of the membrane or translocation across the membranes causing an increase of the membrane permeability. The permeability allows an efflux of essential ions and nutrients leading to rapid cell death [37]. In contrast to prokaryotic membranes, mammalian membranes are enriched with zwitterionic phospholipids (neutral in net charge). Moreover the presence of cholesterol, a major constituent of mammalian membranes, can reduce the activity of APs by stabilizing the lipid bilayer or by directly interacting and neutralizing the APs [38]. The composition of the membranes is likely to provide an important determinant for the AP.

A growing body of evidence indicates that the activity of APs is mediated by intracellular targets. AP molecules pass through and dissociate from the membrane and bind to intracellular targets (Figure 1). They mediate the activation of autolytic enzymes, the inhibition of cell wall biosynthesis and synthesis of DNA, RNA and protein [39]. These intracellular mechanisms can act independently or synergistically with membrane permeabilization. Nevertheless, interaction with the bacterial cell membrane appears to be the killing mechanism of the vast majority of APs [40].

Defensins show microbicidal activity against Gram-positive and -negative bacteria and against various yeast strains such as the opportunistic pathogenic yeast Candida albicans. Interestingly, studies indicate that defensins accumulate at a significantly higher rate and to a greater extent in bacteria- and C. albicans-infected lesions in mice and rabbits compared to non-infected, but inflamed, tissues. These data indicate that peptides distinguish between microorganisms and host tissues, and in doing so, accumulate at sites of infection in vivo [41]. The infection results in a reduced $\mathrm{pH}$, which facilitates the accumulation of the AP.

For cathelicidins, a correlation between their antimicrobial activity and their structure has been observed. A greater extent of $\alpha$-helical conformation is beneficial for their ability to kill both Gram-negative and -positive bacteria [42]. The cathelicidins from sheep and cows, sheep myeloid antimicrobial peptide (SMAP-29) and bovine myeloid antimicrobial peptide (BMAP) respectively, along with the two-disulfide bridged protegrins from pigs, are among the most rapid and potent APs [15]. Another important feature of these peptides is their capacity to bind and neutralize bacterial lipopolysaccharide in vitro, which may account for the ability of exogenously administered peptides to protect against sepsis in vivo $[43,44]$. However, several studies indicate that their activity is sensitive to alterations in the assay conditions, including salt, $\mathrm{pH}$ and the bacterial growth phase [45]. Cathelicidins have cytotoxic effects on eukaryotic cells but this is neutralized by serum components. It is suggested 
that serum lipoproteins play an important role in protecting human cells from damage caused by cathelicidins [42].

Figure 1. The proposed mechanism of action for APs in bacteria. APs are proposed to associate with the negatively charged surface of the outer membrane. The listed models explaining the mechanisms of membrane permeabilization include: (A) barrel-stave: the peptides aggregate and insert into the membrane bilayer in order to align the hydrophobic peptide regions with the lipid core region. The hydrophilic peptide regions form the inner core of the pore. (B) Toroidal: the peptides aggregate and induce the lipid monolayers to bend continuously through the pore so that the water core is lined by both the inserted peptides and the lipid head groups. (C) Carpet channel: the peptides disrupt the membrane by orienting parallel to the surface of the lipid bilayer and forming an extensive layer or carpet. The net effect of $\mathrm{A}$ to $\mathrm{C}$ is that some monomers will be translocated into the cytoplasm and can dissociate from the membrane and bind to cellular polyanions such as DNA and RNA, inhibit enzymatic activity such as protein synthesis or chaperone assisted protein folding. Modified from Brodgen et al. [46].

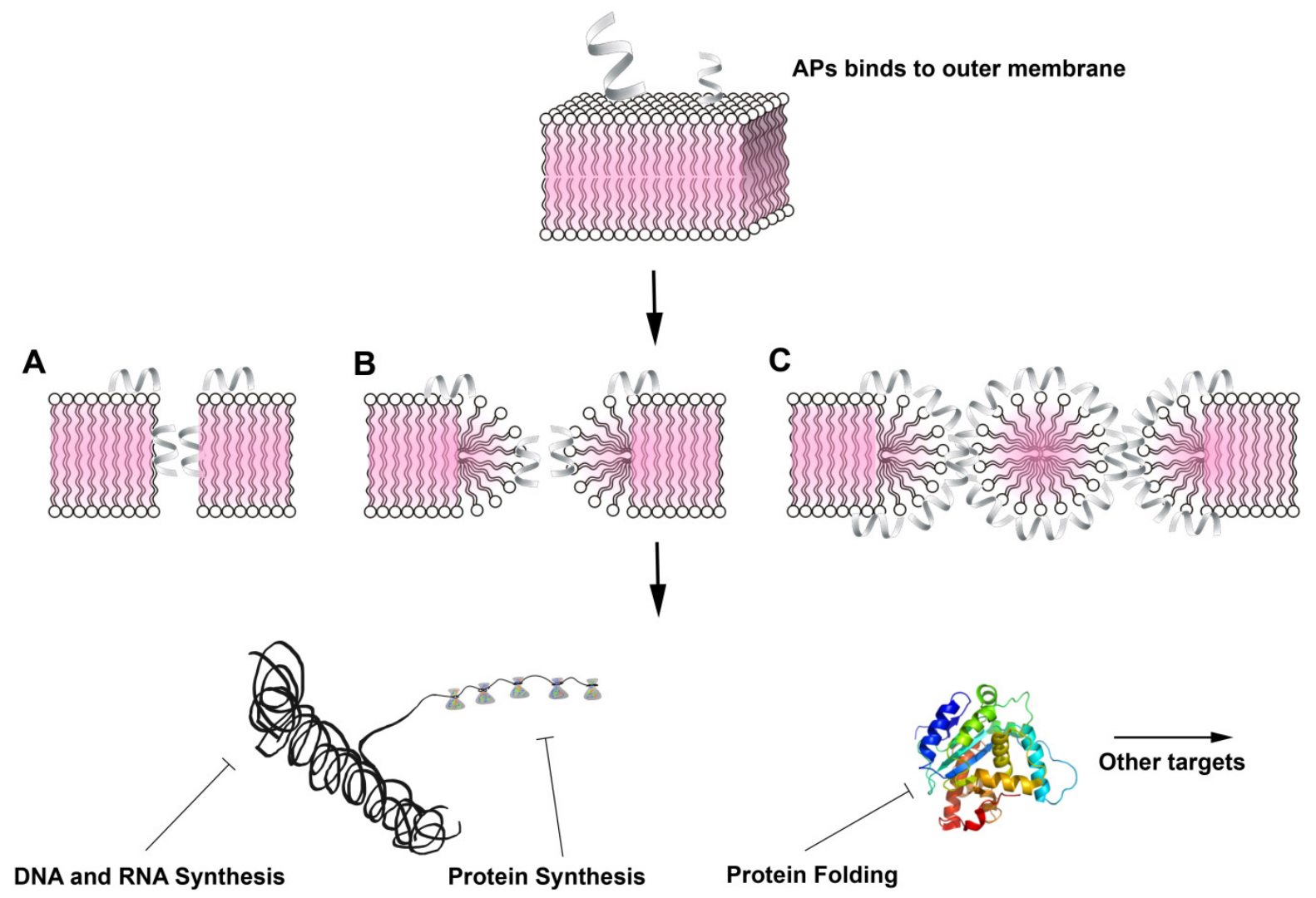

Among histatins, histatin 5 has the strongest antimicrobial activity focusing most of the research on this peptide. It has potent antifungal activity against the pathogens Candida albicans, Cryptococcus neoformans and Aspergillus fumigatus [12]. Like cathelicidins, histatin 5 inhibits the leukotoxic activity of Actinobacillus actinomycetemcomitans [47] and inhibits host and bacterial enzymes implicated in periodontal diseases [48].

Interesting insights into the importance of APs have been shown by several approaches. On the one hand, depletion of AP has been linked to several pathologic disorders. For example patients with specific 
granular deficiency syndrome lack $\alpha$-defensins and suffer from severe and frequent infections [49]. A deficiency in cathelicidin peptide LL-37 and neutrophil peptides (HNP1-3) in humans known as Morbus Kostmann causes patients to suffer from frequent oral bacterial infections and severe periodontal diseases [50]. On the other hand, $\beta$-defensin-1 and CRAMP (cathelin-related antimicrobial peptide; cnlp) gene depletion in knockout mice results in a higher susceptibility to infections and the failure to clear them [9,51,52].

Antiviral activity: In addition to their antibacterial activity, APs possess antiviral activity. The $\alpha$-defensin HNP-1 inhibits the replication of human immunodeficiency virus (HIV) and influenza virus following viral entry into target cells $[53,54]$. Similarly, HNP-1 can inactivate papillomavirus, herpes simplex virus, cytomegalovirus, vesicular stomatitis virus and adenovirus $[55,56]$. Other APs such as human $\beta$ - and synthetic $\theta$-defensins (Retrocyclin 2) or cathelicidins also block HIV-1 replication and influenza virus infections [57-59]. A recent paper using $\beta$-defensin-1 (BD-1) deficient mice showed that BD-1 plays a role in preventing viral replication in immune cells [60]. Besides inhibiting the replication of viruses, defensins inhibit HIV entry into cells by antagonizing the virus proteins that fuse with target cells (glycoprotein gp120/gp41-env) or the cellular receptors involved in virus internalization (chemokine receptor CXCR4) [61,62]. Altogether, several studies show AP potential as broad anti-viral agents. In contrast to antibacterial activity, the antiviral activity seems to depend on an interaction with virus proteins. However, the underlying mechanisms of virus inhibition by APs are far from clear and further investigation needs to be done.

Antifungal activity: Various APs show antifungal activity. The number of identified peptides has been increasing steadily in recent years. The increase in mycoses, the development of resistance to available drugs among fungal pathogens, as well as these drugs' adverse side effects have led to increased efforts to explore the antifungal activity of APs and to identify new candidates for therapy. The mechanisms of AP antifungal action include cell lysis by binding and disruption of the outer membrane, interference with cell wall synthesis and induction of depolymerization of actin cytoskeleton $[63,64]$. The suggested mechanisms seem to be similar to antibacterial models of the AP. Interestingly, in contrast to antiviral peptides, where it appears to be nearly impossible to predict antiviral activity based on secondary structures of the peptide, antifungal peptides tend to be relatively rich in polar and neutral amino acids [65]. Recent results showed that the formation of $\alpha$-helical and/or $\beta$ sheet secondary structures may increase the amphipathicity of the APs and enable them to act specifically with their targets in the fungal membrane [66]. However, the precise mechanisms are not fully understood. For HNP-1 and -2 as well as rabbit NP (1-3), significant activity against Candida spp. has been shown [67,68]. Furthermore, the histatins and cathelicidins also show a high efficiency against Candida and Cryptococcus spp. [69-71]. To date, at least 100 different APs have been investigated for their antifungal activity [72]. As such, APs may represent a new generation of antifungal agents.

Antiparasitic activity: With the identification of the Magainins in the 1980's, studies have shown antiparasitic activity for this AP [73]. Since then, many APs with antiparasitic activities have been identified. At the same time, studies have shown the efficiency of defensins and cathelicidins against the African trypanosome Trypanosoma brucei, the cause of sleeping sickness, by disrupting their cell membrane integrity [24]. More recently, BMAP-18, a truncated form of the bovine myeloid antimicrobial peptide-27 (BMAP-27), exhibited strong action against several parasites, including trypanosomes and Leishmania spp. [74]. At low concentrations, BMAP-18 disrupts mitochondrial 
potential without obvious alteration of parasite plasma membranes, whereas at higher concentrations membrane lesions in the parasites are induced [74]. Studies have suggested that several APs exhibit antiparasitic modes of action resembling their antibacterial, antiviral or antifungal modes of action. For example, the cathelicidin-derived AP PMAP-23 (porcine myeloid antimicrobial peptide-23) exerts antinematodal and antifungal activities by disrupting the cell membrane by pore formation [75]. However, structure-activity relationship studies revealed that the antiparasitic activities of APs may be dependent on certain peptide motifs. These motifs differ from those required for antibacterial, -viral and -fungal activities [65].

\subsection{Immunomodulatory and Further Activities}

In addition to their role as antimicrobial agents, APs participate in multiple aspects of immunity. Early in 1989, Territo et al. [76] demonstrated that neutrophil derived $\alpha$-defensins were chemotactic towards human monocytes for the first time. Over the years, many additional features of APs have been discovered. At present, the hypothesis that immunomodulation is the primary task of the AP is advancing. That the minimal required microbicidal concentrations were rarely found in vivo supports this hypothesis. However, some studies showed local high concentrations of AP at sites of infection and inflammation which were sufficient for a direct killing [77]. Also, the high intracellular AP concentrations in phagocytes, such as neutrophil granulocytes, clearly contribute to direct killing of ingested microbes [34]. Furthermore, several studies have shown the sensitivity of antimicrobial activity to cationic concentrations, serum and anionic macromolecules [78], whereas the immunomodulatory activities appear to be less sensitive [79]. The influence of these functions on innate immunity could represent a novel adjuvant therapy in addition to direct antimicrobial activity. In this context, APs can enhance the potency of existing antibiotics in vivo, probably by facilitating access of antibiotics into the bacterial cell resulting in a synergic effect [80]. Furthermore, APs could act as adjuvants stimulating innate immunity by three basic mechanisms: enhancing recruitment of immune cells to the inflamed site, promoting the activation of those cells and polarizing them to achieve the desired response ( $\mathrm{T}$ helper cells). Altogether, this results in an increase of innate and also adaptive immunity in response to infections. Figure 2 shows a summary for the induction and potential biological role of AP.

APs are primarily chemotactic for immune and non-immune cells. Defensins including $\alpha$-defensins (e.g., HNP1-3) and $\beta$-defensins (human $\beta$-defensin 3 and 4; HBD3 and 4) recruit phagocytes, neutrophil granulocytes and monocytes to the site of inflammation [81]. In addition, HBD1 and HBD3 are chemotactic for immature dendritic cells (iDC) and memory T-cells, whereas human $\alpha$-defensins selectively induce the migration of human native $\mathrm{CD} 4+, \mathrm{CD} 45+$ and $\mathrm{CD} 8+$ cells [81]. The human cathelicidin LL-37 is chemotactic for monocytes, T-cells and neutrophils, but not for dendritic cells. Interestingly, recruitment depends on the G-protein coupled receptor (GPCR) formyl peptide receptor-like 1 (FPRL1; [82]). LL-37 suppresses neutrophil apoptosis via this receptor [83]. Concerning defensins, HBD2 recruit memory T-cells and iDC via GPCR CC-chemokine receptor 6 [84]. In addition to the chemotactic activity, defensins induce mast cell activation, including degranulation, increased prostaglandin D2 production and intracellular $\mathrm{Ca}^{2+}$ mobilization [85]. Beside the direct chemotactic effect, it has been shown that both defensins and cathelicidins act indirectly by inducing chemokines 
such as Chemokine (C-C motif) ligand 2 (CCL2), also known as monocyte chemotactic protein-1 (MCP-1), macrophage inflammatory protein-3 $\alpha$ (MIP-3 $\alpha$; CCL20) and interferon- $\gamma$ inducible protein-10 (IP-10; CXCL10) in human epidermal keratinocytes [86]. Furthermore, recent studies of LL-37 showed an interesting dual role in binding DNA (and RNA) to influence inflammatory response. On the one side, LL-37 is able to bind self-DNA and RNA which activates plasmacytoid dendritic cells (pDCs) in the skin disease psoriasis [87,88]. On the other side, it has been shown that LL-37 interacts and neutralizes psoriasis-associated cytosolic DNA in keratinocytes and blocked AIM2 (DNA sensor interferon-inducible protein absent in melanoma 2) inflammasome activation [89].

Figure 2. Induction, examples of localization and potential biological roles of antimicrobial peptides (APs).

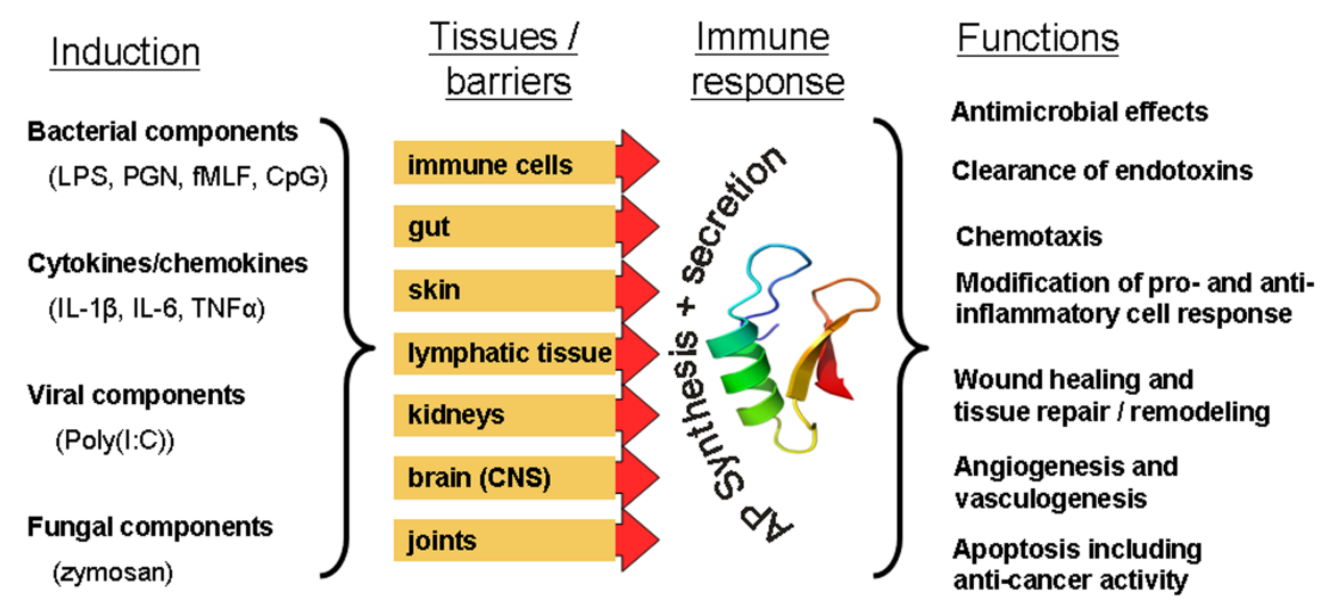

APs also modify pro- and anti-inflammatory cytokine expression to modulate immune response. They influence the balance between induction of inflammation, and at the same time protect the organism from the detrimental effects of an excessive inflammatory response. For example, LL-37 induces potent pro-inflammatory cytokines such as tumor necrosis factor- $\alpha$ (TNF- $\alpha$ ) and interleukin-1 $\beta$ (IL-1 $\beta$ ) in immune and non-immune cells, as well as anti-inflammatory cytokines such as IL-10 in brain glial cells or macrophages [90,91]. Furthermore LL-37 suppresses pro-inflammatory response, including both extracellular neutralization the bacterial cell wall component lipopolysaccharide (LPS) and inhibition of LPS-induced cellular response such as TNF- $\alpha$, nitric oxide and prostaglandin E2 [92,93]. The cytokines themselves are able to increase or decrease AP expression. While TNF- $\alpha$, IL-1 $\beta$ and IL- 6 lead to an increase in the expression of cathelicidin and defensin, IL-10 depresses AP production [10,20,94,95].

The influence of cytokine production, the recruitment of dendritic cells and monocytes to the site of injury, the enhancement of phagocytosis and the maturation of dendritic cells are mediated by APs to modulate adaptive immune functions [90]. All of these effects augment the uptake, processing and presentation of antigens and stimulate the clonal expansion of T-lymphocytes and B-lymphocytes. Previous studies have shown that co-administering of $\alpha$-(HNP-1-3) and $\beta$-defensins (human BD-1 and 2) enhance ovalbumin-specific immunoglobulin $G$ (IgG) response in mice [96,97]. Along with increased iDC maturation, APs induce more effective antigen presentation and subsequent T-cell activation. At the same time, Mader et al. demonstrated that LL-37 induces apoptosis in cytotoxic and regulatory T-cells [98]. 
Interestingly, CRAMP-deficient mice were more susceptible to pathogenic skin infection [18]. In addition, LL-37, HBD-2 and 3 are highly expressed in epidermal keratinocytes in response to injury or infections of the skin $[99,100]$. Therefore, it has been suggested that APs play an important role in maintaining the skin barrier and possibly are involved in its restoration. The hypothesis is supported by several findings: Treatment with HBD-3 induced re-epithelialization of wounds in a porcine model [101]. Growth factors such as insulin-like growth factor I and the transforming growth factor- $\alpha$ have been shown to induce the expression of LL-37 or HBD-3 [99]. Subsequently, the induced APs activate epithelial cells and fibroblasts to form granulation tissue and act chemotatic for macrophages and other immune cells [99]. At the same time APs increase growth factors and cytokine expression in the cells of the skin barrier that induce and control wound healing [8] In addition, Koczulla et al. detected that LL-37 mediates angiogenesis and vasculogenesis [102]. HBD-3 is also involved in tissue remodeling by increasing matrix-metalloproteases protein expression [94]. Altogether, APs appear to be promising candidates for new therapeutic approaches in wound healing. Interestingly, we have been able to show that CRAMP expression in rat glial cells is induced by different neurotrophic factors, for example by neurotrophic growth factor (NGF). CRAMP stimulation also results in an increase in NGF and other neurotrophic factors [103]. We hypothesize that CRAMP is involved in brain protection and promotes neuronal survival following bacterial infection of the brain. Furthermore, recent studies show anticancer activities for APs. For example buforin IIb, a 21-amino acid AP derived from histone H2A, has been shown to induce mitochondrial-dependent apoptosis of tumor cell lines and suppressed growth of tumors implanted in mice [104].

\section{Practical Applications}

Due to increasing development of resistance to classical antibiotics and also because of their antimicrobial and other beneficial activities, APs and their derivatives are very interesting for practical applications. Around 1000 natural APs may serve as lead compounds for future development. However, currently only few APs are approved for clinical use. Interestingly, polymyxin B, a cyclic cationic lipopeptide from Bacillus polymyxa, was discovered in 1947. Since the 1960s polymyxins have been used in topical applications [105]. Further approved drugs are the linear polypeptide gramicidin, derived from Bacillus brevis, as a combination product [106] and daptomycin, a cyclic anionic lipopeptide. Daptomycin is active against Gram-positive bacteria only (skin and soft tissue infections) and is currently the most bactericidal drug on the market used as a reserve antibiotic against opportunistic pathogens (like methicillin-resistant Staphylococcus aureus, MRSA) [107]. Nisin, from Lactococcus lactis, has been used as a food preservative [108]. Furthermore, it should be noted that semisynthetic cyclic lipopeptides (micafungin, anidulafungin) are very effective, clinically approved antifungal APs [109]. The synthetic polypeptide enfuvirtid (fuzeon) from Hoffmann-La Roche inhibits fusion of HIV-1 with host cells. Numerous side effects, high costs and lack of clarity on resistance development have led to controversial discussion of the applications [110].

A good overview of the current situation of clinical trials involving APs is given in the review by Yeung et al. [40]. Of course, the two main functions, the antimicrobial and immunomodulatory activity are in the focus development. There is a possibility that APs may be given for acute infections but also for prophylactic means. However, the three candidates present in the clinical trial phase III, omiganan, 
pexiganan (from frog magainin) and iseganan, have failed to achieve New Drug Application (NDA) approval because of unresolved issues with clinical trial design, endpoints and failure to demonstrate an advantage over existing therapeutics [40]. Another application in a clinical trial is acne treatment. Acne lesions by Propionibacterium acnes are associated with moderate-to-severe inflammation; a treatment involving both antimicrobial and anti-inflammatory agents would be of significant benefit. That could be improved by an indolicidin-derived peptide named MBI-594AN from Migenix. This peptide is not only antimicrobial against $P$. acnes, but also suppresses $P$. acnes-stimulated cytokine release [111]. A further candidate from Migenix MX-226 (omiganan), a synthetic cationic host defense peptide derived from indolicidin, should be used to prevent catheter infections and is also topical antiseptic for burn wounds [112].

Systemic applications have previously been considered. To date, cost-effectiveness, poor pharmacokinetics (due to AP susceptibility to proteases) and unknown toxicity have limited the use for topical applications. There have been some recent developments in efforts to solve these problems. For example, the susceptibility of APs to protease degradation may be resolvable by a variety of strategies, including formulations as prodrugs, peptidomimetics equivalent to APs and the use of D- or nonnatural amino acids $[113,114]$. Polymedix (USA) developed de novo-designed series of polymeric, oligomeric and small molecule mimetics of APs (PMX series). In particular, the lead compound PMX30063 is now under preclinical development for broad spectrum systemic infections $[115,116]$. There are many new approaches in the literature for APs, which show a good preclinical antimicrobial activity. For example the derivative NZ2114 from the defensin-like AP plectasin (isolated from the saprophytic fungus Pseudoplectania nigrella) shows high in vivo efficacy against MRSA in experimental endocarditis or Streptococcus pneumoniae in meningitis or pneumonia [117,118].

Besides broad-spectrum activity against bacteria, comparable to that of antibiotics, APs also show antiviral and/or antifungal activities. For example, in cases of infection with viruses or with parasites that can hide in host cells, dermaseptin peptides, now used in wound and skin unguents, have been shown to act on human erythrocytes infected by the malaria parasite Plasmodium falciparum [119]. A range of acyl modifications have been prepared with $\mathrm{N}$-terminal peptide fragments of dermaseptin derivatives, linear cationic peptides isolated from amphibian skin. Those lipopeptides exhibit fast bactericidal activity against biofilms of oral pathogens such as Streptococcus mutans and Actinomyces viscosus [120]. Plasticins, as members of the dermaseptin superfamily, are membrane-damaging peptides [121]. The human lactoferrin-derived peptide hLF1-11, now in phase I/II, is intended for treatment of fungal infections [122]. The peptide shows also a high efficiency against MRSA.

Furthermore, APs have multiple targets within the cell, including membrane barrier disruption and inhibition of intracellular targets. Apparently, multiple targets reduce the risk of resistance against APs in microbes. Although resistance has been demonstrated in vitro, it seems to develop more slowly than resistance to antibiotics [123]. Nevertheless, pathogens devise several mechanisms to protect themselves from the deleterious effects of APs [124]. Bacterial sensing systems are well conserved among pathogens and may present attractive targets for the development of new antimicrobials. There is a possibility that a combined administration of different APs would improve efficacy both in terms of combined mechanisms of action and the avoidance of resistance development. As mentioned above, several studies have reported synergistic effects between APs and conventional antibiotics by 
membranolytic action or facilitating access to intracellular targets via the membrane-permeabilizing activity of the AP [125].

Besides acute applications, the latest developments have shown bioactive implant coatings with APs to protect against pathogen colonization and infection after surgery. For example, Pfeufer et al. report the effectiveness of titanium surfaces coated with recombinated HBD-2 with respect to antibacterial activity and suggest that this may be a promising tool for treating infections related to prosthetic implant surgery [126]. Our own studies show promising results with the HBD-2 coating of a Kirschner-wire (Figure 3). Another application, in which effectiveness has been demonstrated, is the use of an occlusive silk membrane loaded with colistin (trade name for polymyxin E) for treatment of infected wounds [127]. Furthermore, coated APs are used to prevent the biofilm formation on implants [128]. There are several in vitro studies with defensins or histatin as antimicrobial films. Multilayer films, functionalized by insertion of defensins, inhibit growth of infectious pathogens. Polypeptide multilayer thin films incorporating APs therefore are considered promising in the protection of implants, catheters, needles, surgical tools, tubes and many other kinds of materials from proliferation of microorganisms [129]. A further approach is the coating of contact lenses with the AP melamine, which resulted in a prevention of bacterial growth on contact lenses and consequently results in the reduction of the incidence and severity of adverse responses due to Gram-positive and -negative bacteria during lens wear [130].

The immunomodulatory activity of APs suggests further potential uses. This includes applications in wound healing, as vaccine adjuvants, use in anti-endotoxemia and as anticancer drugs. An important advantage of APs is the synergistic effects of various peptides. By using multiple APs, antimicrobial activity can be enhanced or complemented with other functions such as immunomodulatory activity or with anti-endotoxin (LPS) compounds. Opebacan, a derivative of human bactericidal/permeabilityincreasing protein, now in Phase I/II, kills bacteria and neutralizes the action of LPS [131]. Besides antifungal activity, hLF1-11 induces monocyte differentiation towards macrophages with enhanced recognition and clearance of pathogens [122]. Furthermore, the rationally designed D-amino acid decapeptide RDP58 has been proven safe in clinical trials. The peptide reduces proinflammatory cytokine response by inhibiting intracellular inflammation pathways. The application as an innate defense regulator is planned for various inflammatory diseases, such as inflammatory bowel disease, arthritis, asthma or intestinal cystitis [132]. Defensins have been suggested to be antiangiogenic [133]. Such an activity may provide new insights for developing a novel class of antiangiogenetic drugs to combat tumor growth and cancer. A derivative from the AP cecropin B, a small antibacterial peptide from the giant silkmoth, Hyalophora cecropia, HB-107 developed by Helix Biomedix, Inc., enhances wound repair compared with scrambled peptide and vehicle controls, an effect comparable to treatment with recombinant human platelet-derived growth factor- $\beta$. Wounds treated with HB-107 show keratinocyte hyperplasia and increased leukocyte infiltration [134]. Altogether, the coming years will certainly reveal more interesting and promising details in this area. 
Figure 3. HBD-2-coated Kirschner-wire used for fracture fixation shows antimicrobial activity against Gram-negative bacteria. The wire was coated with poly-DL-lactide (PDLLA) (A) or PDLLA and HBD-2 (3 $\mu \mathrm{g})(\mathbf{B})$, and the antibacterial activity against the Gram-negative bacterium Pseudomonas aeruginosa was tested using agar diffusion test. For description of the agar diffusion test please see [10]. Briefly, bacterial suspension was mixed with underlay agar, poured into Petri dishes, and the Kirschner-wire was inserted. After overnight incubation at $37^{\circ} \mathrm{C}$, overlay agar was poured onto the underlay agar. Agar plates were incubated at $37^{\circ} \mathrm{C}$ for $4 \mathrm{~h}$ and the growth inhibition zones were examined.
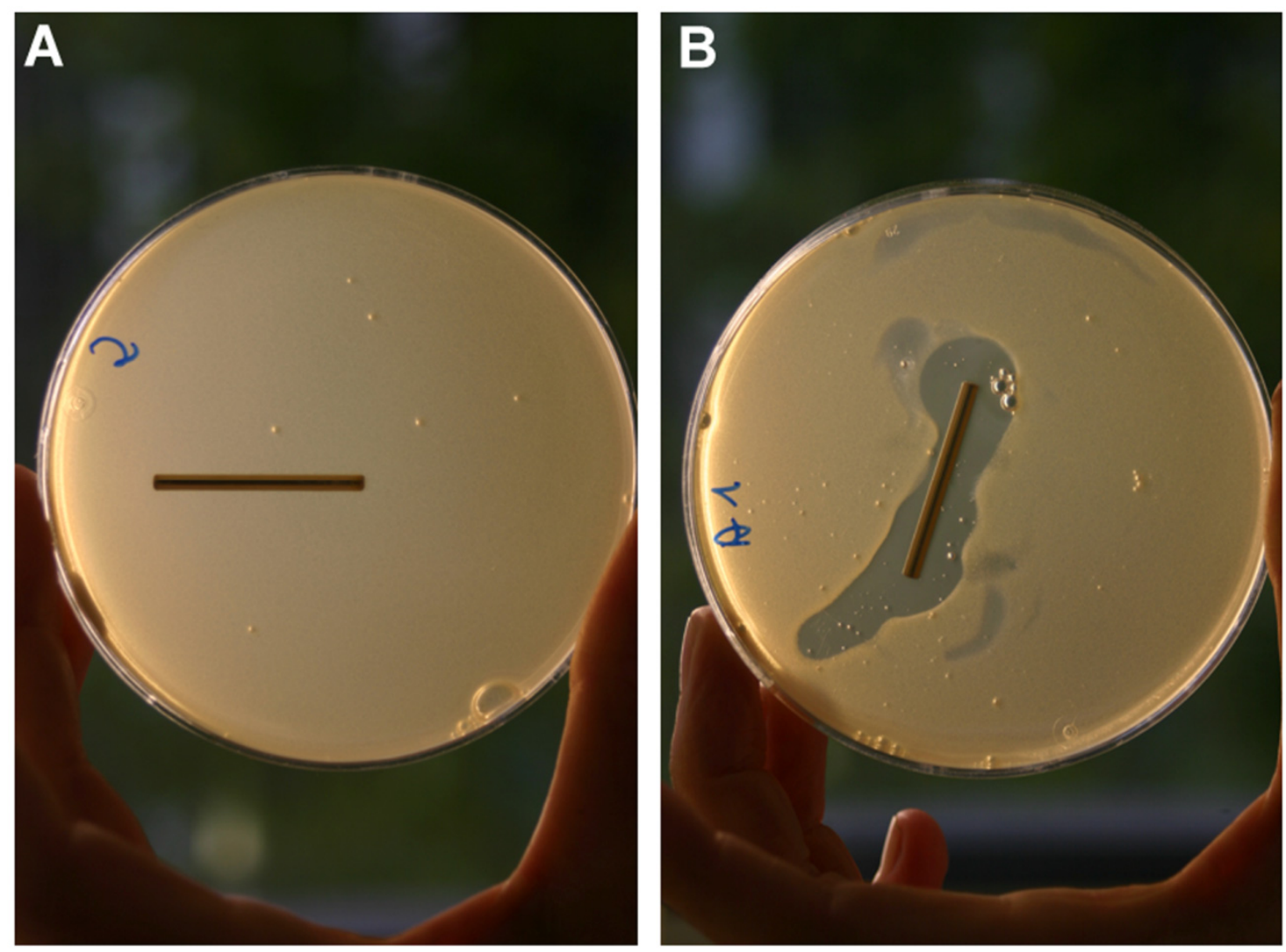

\section{Conclusions and Future Perspectives}

In recent decades, the understanding of the biological importance of APs has greatly increased. On the one hand, an attempt has been made to enhance and improve antimicrobial activity. On the other hand, their diverse immunomodulatory activities increase the potential for further applications of APs in areas including wound healing, anti-LPS, as innate defense regulators and as anticancer drugs. However, for a broader application, present problems such as cost, stability against proteolytic degradation, susceptibility to salt, $\mathrm{pH}$ and serum, unclear cytotoxicity towards eukaryotes and effectiveness around standard antibiotics must be solved. Recent findings and developments have even shown some possible solutions. From this perspective, APs are certainly no panacea, but they offer interesting possibilities for the application with new targets. For example, new innovative approaches may be represented by understanding of the development of resistance in microbes against APs, along with innate immunity regulation involving chemotaxis or modulation of inflammatory pathways by APs. Furthermore, APs can also help us understand the complex relationships and interaction between 
organisms in the form of the immune system and pathogens. APs definitely contribute to the maintenance of balance between inflammation and homeostasis. This means they are an indispensable component of the innate immune system. This makes them attractive as potential sensors and biomarkers in early detection and prevention of diseases such as sepsis.

In conclusion, although there are few APs in current clinical use, and it is not unlikely that the use of APs as therapeutics will increase sharply in the coming years. This includes their use as antimicrobials as well as adjuvant use to support other treatments.

\section{Acknowledgments}

We thank Wolfgang Graulich for the production of the illustration. We gratefully acknowledge financial support from the Else Kröner-Fresenius-Stiftung (L.O.B.) and START-Program of the RWTH Aachen University (L.O.B.) and from the Deutsche Forschungsgemeinschaft (DFG; SFB 617 A22 to D.V. and T.P.).

\section{References}

1. Zasloff, M. Magainins, a class of antimicrobial peptides from xenopus skin: Isolation, characterization of two active forms, and partial cdna sequence of a precursor. Proc. Natl. Acad. Sci. USA 1987, 84, 5449-5453.

2. Zasloff, M.; Martin, B.; Chen, H.C. Antimicrobial activity of synthetic magainin peptides and several analogues. Proc. Natl. Acad. Sci. USA 1988, 85, 910-913.

3. Bulet, P.; Stocklin, R.; Menin, L. Anti-microbial peptides: From invertebrates to vertebrates. Immunol. Rev. 2004, 198, 169-184.

4. Kasahara, M.; Suzuki, T.; Pasquier, L.D. On the origins of the adaptive immune system: Novel insights from invertebrates and cold-blooded vertebrates. Trends Immunol. 2004, 25, 105-111.

5. Stotz, H.U.; Thomson, J.G.; Wang, Y. Plant defensins: Defense, development and application. Plant Signal. Behav. 2009, 4, 1010-1012.

6. Zasloff, M. Antimicrobial peptides of multicellular organisms. Nature 2002, 415, 389-395.

7. Varoga, D.; Pufe, T.; Mentlein, R.; Kohrs, S.; Grohmann, S.; Tillmann, B.; Hassenpflug, J.; Paulsen, F. Expression and regulation of antimicrobial peptides in articular joints. Ann. Anat. 2005, 187, 499-508.

8. Schroder, J.M. The role of keratinocytes in defense against infection. Curr. Opin. Infect. Dis. 2010, 23, 106-110.

9. Bergman, P.; Johansson, L.; Wan, H.; Jones, A.; Gallo, R.L.; Gudmundsson, G.H.; Hokfelt, T.; Jonsson, A.B.; Agerberth, B. Induction of the antimicrobial peptide cramp in the blood-brain barrier and meninges after meningococcal infection. Infect. Immun. 2006, 74, 6982-6991.

10. Brandenburg, L.O.; Varoga, D.; Nicolaeva, N.; Leib, S.L.; Podschun, R.; Wruck, C.J.; Wilms, H.; Lucius, R.; Pufe, T. Expression and regulation of antimicrobial peptide rcramp after bacterial infection in primary rat meningeal cells. J. Neuroimmunol. 2009, 217, 55-64.

11. Zaiou, M. Multifunctional antimicrobial peptides: Therapeutic targets in several human diseases. J. Mol. Med. 2007, 85, 317-329. 
12. De Smet, K.; Contreras, R. Human antimicrobial peptides: Defensins, cathelicidins and histatins. Biotechnol. Lett. 2005, 27, 1337-1347.

13. Wang, G.; Li, X.; Wang, Z. APD2: the updated antimicrobial peptide database and its application in peptide design. Nucleic Acids Res 2009, 37, D933-937.

14. Ganz, T. Defensins: Antimicrobial peptides of innate immunity. Nat. Rev. Immunol. 2003, 3, 710-720.

15. Zanetti, M. The role of cathelicidins in the innate host defenses of mammals. Curr. Issues Mol. Biol. 2005, 7, 179-196.

16. Gudmundsson, G.H.; Agerberth, B.; Odeberg, J.; Bergman, T.; Olsson, B.; Salcedo, R. The human gene fall39 and processing of the cathelin precursor to the antibacterial peptide 11-37 in granulocytes. Eur. J. Biochem. 1996, 238, 325-332.

17. Frohm, M.; Agerberth, B.; Ahangari, G.; Stahle-Backdahl, M.; Liden, S.; Wigzell, H.; Gudmundsson, G.H. The expression of the gene coding for the antibacterial peptide 11-37 is induced in human keratinocytes during inflammatory disorders. J. Biol. Chem. 1997, 272, $15258-15263$.

18. Nizet, V.; Ohtake, T.; Lauth, X.; Trowbridge, J.; Rudisill, J.; Dorschner, R.A.; Pestonjamasp, V.; Piraino, J.; Huttner, K.; Gallo, R.L. Innate antimicrobial peptide protects the skin from invasive bacterial infection. Nature 2001, 414, 454-457.

19. Bergman, P.; Termen, S.; Johansson, L.; Nystrom, L.; Arenas, E.; Jonsson, A.B.; Hokfelt, T.; Gudmundsson, G.H.; Agerberth, B. The antimicrobial peptide rcramp is present in the central nervous system of the rat. $J$. Neurochem. 2005, 93, 1132-1140.

20. Brandenburg, L.O.; Varoga, D.; Nicolaeva, N.; Leib, S.L.; Wilms, H.; Podschun, R.; Wruck, C.J.; Schroder, J.M.; Pufe, T.; Lucius, R. Role of glial cells in the functional expression of 11-37/rat cathelin-related antimicrobial peptide in meningitis. J. Neuropathol. Exp. Neurol. 2008, 67, 1041-1054.

21. Larrick, J.W.; Hirata, M.; Balint, R.F.; Lee, J.; Zhong, J.; Wright, S.C. Human cap18: A novel antimicrobial lipopolysaccharide-binding protein. Infect. Immun. 1995, 63, 1291-1297.

22. Huttner, K.M.; Bevins, C.L. Antimicrobial peptides as mediators of epithelial host defense. Pediatr. Res. 1999, 45, 785-794.

23. Nizet, V.; Gallo, R.L. Cathelicidins and innate defense against invasive bacterial infection. Scand. J. Infect. Dis. 2003, 35, 670-676.

24. McGwire, B.S.; Olson, C.L.; Tack, B.F.; Engman, D.M. Killing of african trypanosomes by antimicrobial peptides. J. Infect. Dis. 2003, 188, 146-152.

25. Tarasov, V.A.; Khadeeva, N.V.; Mel'nik, V.A.; Ezhova, T.A.; Shestakov, S.V. The atlg12860 gene of arabidopsis thaliana determines cathelicidin-like antimicrobial activity. Dokl. Biol. Sci. 2009, 427, 332-334.

26. Ahmad, M.; Piludu, M.; Oppenheim, F.G.; Helmerhorst, E.J.; Hand, A.R. Immunocytochemical localization of histatins in human salivary glands. J. Histochem. Cytochem. 2004, 52, 361-370.

27. Padovan, L.; Segat, L.; Pontillo, A.; Antcheva, N.; Tossi, A.; Crovella, S. Histatins in non-human primates: Gene variations and functional effects. Protein Pept. Lett. 2010, 17, 909-918.

28. Froy, O. Regulation of mammalian defensin expression by toll-like receptor-dependent and independent signalling pathways. Cell Microbiol. 2005, 7, 1387-1397. 
29. Braun, B.J.; Slowik, A.; Leib, S.L.; Lucius, R.; Varoga, D.; Wruck, C.J.; Jansen, S.; Podschun, R.; Pufe, T.; Brandenburg, L.O. The formyl peptide receptor like-1 and scavenger receptor marco are involved in glial cell activation in bacterial meningitis. J. Neuroinflammation 2011, 8, 11-15.

30. Lehrer, R.I.; Lu, W. Alpha-defensins in human innate immunity. Immunol. Rev. 2012, 245, 84-112.

31. Pazgier, M.; Li, X.; Lu, W.; Lubkowski, J. Human defensins: Synthesis and structural properties. Curr. Pharm. Des. 2007, 13, 3096-3118.

32. Tongaonkar, P.; Tran, P.; Roberts, K.; Schaal, J.; Osapay, G.; Tran, D.; Ouellette, A.J.; Selsted, M.E. Rhesus macaque theta-defensin isoforms: Expression, antimicrobial activities, and demonstration of a prominent role in neutrophil granule microbicidal activities. J. Leukoc. Biol. 2011, 89, 283-290.

33. Bucki, R.; Leszczynska, K.; Namiot, A.; Sokolowski, W. Cathelicidin 11-37: A multitask antimicrobial peptide. Arch. Immunol. Ther. Exp. (Warsz.) 2010, 58, 15-25.

34. Wiesner, J.; Vilcinskas, A. Antimicrobial peptides: The ancient arm of the human immune system. Virulence 2010, 1, 440-464.

35. Diamond, G.; Beckloff, N.; Weinberg, A.; Kisich, K.O. The roles of antimicrobial peptides in innate host defense. Curr. Pharm. Des. 2009, 15, 2377-2392.

36. Mihajlovic, M.; Lazaridis, T. Antimicrobial peptides in toroidal and cylindrical pores. Biochim. Biophys. Acta 2010, 1798, 1485-1493.

37. Giuliani, A.; Pirri, G.; Bozzi, A.; Di Giulio, A.; Aschi, M.; Rinaldi, A.C. Antimicrobial peptides: Natural templates for synthetic membrane-active compounds. Cell Mol. Life Sci. 2008, 65, 2450-2460.

38. Matsuzaki, K. Why and how are peptide-lipid interactions utilized for self-defense? Magainins and tachyplesins as archetypes. Biochim. Biophys. Acta 1999, 1462, 1-10.

39. Yeaman, M.R.; Yount, N.Y. Mechanisms of antimicrobial peptide action and resistance. Pharmacol. Rev. 2003, 55, 27-55.

40. Yeung, A.T.; Gellatly, S.L.; Hancock, R.E. Multifunctional cationic host defense peptides and their clinical applications. Cell Mol. Life Sci. 2011, 68, 2161-2176.

41. Welling, M.M.; Lupetti, A.; Balter, H.S.; Lanzzeri, S.; Souto, B.; Rey, A.M.; Savio, E.O.; Paulusma-Annema, A.; Pauwels, E.K.; Nibbering, P.H. 99mtc-labeled antimicrobial peptides for detection of bacterial and candida albicans infections. J. Nucl. Med. 2001, 42, 788-794.

42. Johansson, J.; Gudmundsson, G.H.; Rottenberg, M.E.; Berndt, K.D.; Agerberth, B. Conformation-dependent antibacterial activity of the naturally occurring human peptide 11-37. J. Biol. Chem. 1998, 273, 3718-3724.

43. Wiese, A.; Gutsmann, T.; Seydel, U. Towards antibacterial strategies: Studies on the mechanisms of interaction between antibacterial peptides and model membranes. J. Endotoxin Res. 2003, 9, 67-84.

44. Warren, H.S.; Matyal, R.; Allaire, J.E.; Yarmush, D.; Loiselle, P.; Hellman, J.; Paton, B.G.; Fink, M.P. Protective efficacy of cap18106-138-immunoglobulin g in sepsis. J. Infect. Dis. 2003, 188, 1382-1393.

45. Kai-Larsen, Y.; Agerberth, B. The role of the multifunctional peptide 11-37 in host defense. Front. Biosci. 2008, 13, 3760-3767. 
46. Brogden, K.A. Antimicrobial peptides: Pore formers or metabolic inhibitors in bacteria? Nat. Rev. Microbiol. 2005, 3, 238-250.

47. Murakami, Y.; Xu, T.; Helmerhorst, E.J.; Ori, G.; Troxler, R.F.; Lally, E.T.; Oppenheim, F.G. Inhibitory effect of synthetic histatin 5 on leukotoxin from actinobacillus actinomycetemcomitans. Oral Microbiol. Immunol. 2002, 17, 143-149.

48. Gusman, H.; Travis, J.; Helmerhorst, E.J.; Potempa, J.; Troxler, R.F.; Oppenheim, F.G. Salivary histatin 5 is an inhibitor of both host and bacterial enzymes implicated in periodontal disease. Infect. Immun. 2001, 69, 1402-1408.

49. Ganz, T.; Metcalf, J.A.; Gallin, J.I.; Boxer, L.A.; Lehrer, R.I. Microbicidal/cytotoxic proteins of neutrophils are deficient in two disorders: Chediak-higashi syndrome and "Specific" Granule deficiency. J. Clin. Invest. 1988, 82, 552-556.

50. Putsep, K.; Carlsson, G.; Boman, H.G.; Andersson, M. Deficiency of antibacterial peptides in patients with morbus kostmann: An observation study. Lancet 2002, 360, 1144-1149.

51. Moser, C.; Weiner, D.J.; Lysenko, E.; Bals, R.; Weiser, J.N.; Wilson, J.M. Beta-defensin 1 contributes to pulmonary innate immunity in mice. Infect. Immun. 2002, 70, 3068-3072.

52. Huang, L.C.; Reins, R.Y.; Gallo, R.L.; McDermott, A.M. Cathelicidin-deficient (cnlp -/-) mice show increased susceptibility to pseudomonas aeruginosa keratitis. Invest. Ophthalmol. Vis. Sci. 2007, 48, 4498-4508.

53. Zhang, K.; Lu, Q.; Zhang, Q.; Hu, X. Regulation of activities of nk cells and cd4 expression in $\mathrm{t}$ cells by human hnp-1, -2, and -3. Biochem. Biophys. Res. Commun. 2004, 323, 437-444.

54. Salvatore, M.; Garcia-Sastre, A.; Ruchala, P.; Lehrer, R.I.; Chang, T.; Klotman, M.E. Alpha-defensin inhibits influenza virus replication by cell-mediated mechanism(s). J. Infect. Dis. 2007, 196, 835-843.

55. Buck, C.B.; Day, P.M.; Thompson, C.D.; Lubkowski, J.; Lu, W.; Lowy, D.R.; Schiller, J.T. Human alpha-defensins block papillomavirus infection. Proc. Natl. Acad. Sci. USA 2006, 103, 1516-1521.

56. Daher, K.A.; Selsted, M.E.; Lehrer, R.I. Direct inactivation of viruses by human granulocyte defensins. J. Virol. 1986, 60, 1068-1074.

57. Bergman, P.; Walter-Jallow, L.; Broliden, K.; Agerberth, B.; Soderlund, J. The antimicrobial peptide 11-37 inhibits hiv-1 replication. Curr. HIV Res. 2007, 5, 410-415.

58. Braida, L.; Boniotto, M.; Pontillo, A.; Tovo, P.A.; Amoroso, A.; Crovella, S. A single-nucleotide polymorphism in the human beta-defensin 1 gene is associated with hiv-1 infection in italian children. Aids 2004, 18, 1598-1600.

59. Liang, Q.L.; Zhou, K.; He, H.X. Retrocyclin 2: A new therapy against avian influenza h5n1 virus in vivo and vitro. Biotechnol. Lett. 2010, 32, 387-392.

60. Ryan, L.K.; Dai, J.; Yin, Z.; Megjugorac, N.; Uhlhorn, V.; Yim, S.; Schwartz, K.D.; Abrahams, J.M.; Diamond, G.; Fitzgerald-Bocarsly, P. Modulation of human beta-defensin-1 (hbd-1) in plasmacytoid dendritic cells (pdc), monocytes, and epithelial cells by influenza virus, herpes simplex virus, and sendai virus and its possible role in innate immunity. J. Leukoc. Biol. 2011, 90, 343-356. 
61. Gallo, S.A.; Wang, W.; Rawat, S.S.; Jung, G.; Waring, A.J.; Cole, A.M.; Lu, H.; Yan, X.; Daly, N.L.; Craik, D.J.; et al. Theta-defensins prevent hiv-1 env-mediated fusion by binding gp41 and blocking 6-helix bundle formation. J. Biol. Chem. 2006, 281, 18787-18792.

62. Feng, Z.; Dubyak, G.R.; Lederman, M.M.; Weinberg, A. Cutting edge: Human beta defensin 3-A novel antagonist of the hiv-1 coreceptor cxcr4. J. Immunol. 2006, 177, 782-786.

63. Koo, J.C.; Lee, B.; Young, M.E.; Koo, S.C.; Cooper, J.A.; Baek, D.; Lim, C.O.; Lee, S.Y.; Yun, D.J.; Cho, M.J. Pn-amp1, a plant defense protein, induces actin depolarization in yeasts. Plant Cell Physiol. 2004, 45, 1669-1680.

64. De Lucca, A.J.; Walsh, T.J. Antifungal peptides: Novel therapeutic compounds against emerging pathogens. Antimicrob. Agents Chemother. 1999, 43, 1-11.

65. Jenssen, H.; Hamill, P.; Hancock, R.E. Peptide antimicrobial agents. Clin. Microbiol. Rev. 2006, 19, 491-511.

66. Matejuk, A.; Leng, Q.; Begum, M.D.; Woodle, M.C.; Scaria, P.; Chou, S.T.; Mixson, A.J. Peptide-based antifungal therapies against emerging infections. Drugs Future 2010, 35, 197.

67. Lehrer, R.I.; Ganz, T.; Szklarek, D.; Selsted, M.E. Modulation of the in vitro candidacidal activity of human neutrophil defensins by target cell metabolism and divalent cations. J. Clin. Invest. 1988, 81, 1829-1835.

68. Selsted, M.E.; Szklarek, D.; Ganz, T.; Lehrer, R.I. Activity of rabbit leukocyte peptides against candida albicans. Infect. Immun. 1985, 49, 202-206.

69. Helmerhorst, E.J.; Reijnders, I.M.; van't Hof, W.; Simoons-Smit, I.; Veerman, E.C.; Amerongen, A.V. Amphotericin b- and fluconazole-resistant candida spp., aspergillus fumigatus, and other newly emerging pathogenic fungi are susceptible to basic antifungal peptides. Antimicrob. Agents Chemother. 1999, 43, 702-704.

70. Tsai, H.; Bobek, L.A. Human salivary histatin-5 exerts potent fungicidal activity against cryptococcus neoformans. Biochim. Biophys. Acta 1997, 1336, 367-369.

71. Benincasa, M.; Scocchi, M.; Pacor, S.; Tossi, A.; Nobili, D.; Basaglia, G.; Busetti, M.; Gennaro, R. Fungicidal activity of five cathelicidin peptides against clinically isolated yeasts. J. Antimicrob. Chemother. 2006, 58, 950-959.

72. Lupetti, A.; Danesi, R.; van't Wout, J.W.; van Dissel, J.T.; Senesi, S.; Nibbering, P.H. Antimicrobial peptides: Therapeutic potential for the treatment of candida infections. Expert Opin. Investig. Drugs 2002, 11, 309-318.

73. Huang, C.M.; Chen, H.C.; Zierdt, C.H. Magainin analogs effective against pathogenic protozoa. Antimicrob. Agents Chemother. 1990, 34, 1824-1826.

74. Haines, L.R.; Thomas, J.M.; Jackson, A.M.; Eyford, B.A.; Razavi, M.; Watson, C.N.; Gowen, B.; Hancock, R.E.; Pearson, T.W. Killing of trypanosomatid parasites by a modified bovine host defense peptide, bmap-18. PLoS Negl. Trop. Dis. 2009, 3, doi:10.1371/journal.pntd.0000373.g007.

75. Park, Y.; Jang, S.H.; Lee, D.G.; Hahm, K.S. Antinematodal effect of antimicrobial peptide, pmap-23, isolated from porcine myeloid against caenorhabditis elegans. J. Pept. Sci. 2004, 10, 304-311.

76. Territo, M.C.; Ganz, T.; Selsted, M.E.; Lehrer, R. Monocyte-chemotactic activity of defensins from human neutrophils. J. Clin. Invest. 1989, 84, 2017-2020. 
77. Auvynet, C.; Rosenstein, Y. Multifunctional host defense peptides: Antimicrobial peptides, the small yet big players in innate and adaptive immunity. FEBS J. 2009, 276, 6497-6508.

78. Weidenmaier, C.; Kristian, S.A.; Peschel, A. Bacterial resistance to antimicrobial host defensesAn emerging target for novel antiinfective strategies? Curr. Drug Targets 2003, 4, 643-649.

79. Nijnik, A.; Madera, L.; Ma, S.; Waldbrook, M.; Elliott, M.R.; Easton, D.M.; Mayer, M.L.; Mullaly, S.C.; Kindrachuk, J.; Jenssen, H.; et al. Synthetic cationic peptide idr-1002 provides protection against bacterial infections through chemokine induction and enhanced leukocyte recruitment. J. Immunol. 2010, 184, 2539-2550.

80. Giacometti, A.; Cirioni, O.; Barchiesi, F.; Scalise, G. In vitro activity and killing effect of polycationic peptides on methicillin-resistant staphylococcus aureus and interactions with clinically used antibiotics. Diagn. Microbiol. Infect. Dis. 2000, 38, 115-118.

81. Lai, Y.; Gallo, R.L. Amped up immunity: How antimicrobial peptides have multiple roles in immune defense. Trends Immunol. 2009, 30, 131-141.

82. Yang, D.; Chertov, O.; Oppenheim, J.J. Participation of mammalian defensins and cathelicidins in anti-microbial immunity: Receptors and activities of human defensins and cathelicidin (11-37). J. Leukoc. Biol. 2001, 69, 691-697.

83. Nagaoka, I.; Tamura, H.; Hirata, M. An antimicrobial cathelicidin peptide, human cap18/11-37, suppresses neutrophil apoptosis via the activation of formyl-peptide receptor-like 1 and $\mathrm{p} 2 \mathrm{x} 7$. J. Immunol. 2006, 176, 3044-3052.

84. Yang, D.; Chertov, O.; Bykovskaia, S.N.; Chen, Q.; Buffo, M.J.; Shogan, J.; Anderson, M.; Schroder, J.M.; Wang, J.M.; Howard, O.M.; et al. Beta-defensins: Linking innate and adaptive immunity through dendritic and t cell ccr6. Science 1999, 286, 525-528.

85. Chen, X.; Niyonsaba, F.; Ushio, H.; Hara, M.; Yokoi, H.; Matsumoto, K.; Saito, H.; Nagaoka, I.; Ikeda, S.; Okumura, K.; et al. Antimicrobial peptides human beta-defensin (hbd)-3 and hbd-4 activate mast cells and increase skin vascular permeability. Eur. J. Immunol. 2007, 37, 434-444.

86. Niyonsaba, F.; Ushio, H.; Nakano, N.; Ng, W.; Sayama, K.; Hashimoto, K.; Nagaoka, I.; Okumura, K.; Ogawa, H. Antimicrobial peptides human beta-defensins stimulate epidermal keratinocyte migration, proliferation and production of proinflammatory cytokines and chemokines. J. Invest. Dermatol. 2007, 127, 594-604.

87. Ganguly, D.; Chamilos, G.; Lande, R.; Gregorio, J.; Meller, S.; Facchinetti, V.; Homey, B.; Barrat, F.J.; Zal, T.; Gilliet, M. Self-rna-antimicrobial peptide complexes activate human dendritic cells through tlr7 and tlr8. J. Exp. Med. 2009, 206, 1983-1994.

88. Lande, R.; Gregorio, J.; Facchinetti, V.; Chatterjee, B.; Wang, Y.H.; Homey, B.; Cao, W.; Wang, Y.H.; Su, B.; Nestle, F.O.; et al. Plasmacytoid dendritic cells sense self-DNA coupled with antimicrobial peptide. Nature 2007, 449, 564-569.

89. Dombrowski, Y.; Peric, M.; Koglin, S.; Kammerbauer, C.; Goss, C.; Anz, D.; Simanski, M.; Glaser, R.; Harder, J.; Hornung, V.; et al. Cytosolic DNA triggers inflammasome activation in keratinocytes in psoriatic lesions. Sci. Transl. Med. 2011, 3, doi:10.1126/scitranslmed.3002001.

90. Davidson, D.J.; Currie, A.J.; Reid, G.S.; Bowdish, D.M.; MacDonald, K.L.; Ma, R.C.; Hancock, R.E.; Speert, D.P. The cationic antimicrobial peptide 11-37 modulates dendritic cell differentiation and dendritic cell-induced t cell polarization. J. Immunol. 2004, 172, 1146-1156. 
91. van der Does, A.M.; Beekhuizen, H.; Ravensbergen, B.; Vos, T.; Ottenhoff, T.H.; van Dissel, J.T.; Drijfhout, J.W.; Hiemstra, P.S.; Nibbering, P.H. L1-37 directs macrophage differentiation toward macrophages with a proinflammatory signature. J. Immunol. 2010, 185, 1442-1449.

92. Scott, M.G.; Vreugdenhil, A.C.; Buurman, W.A.; Hancock, R.E.; Gold, M.R. Cutting edge: Cationic antimicrobial peptides block the binding of lipopolysaccharide (lps) to lps binding protein. J. Immunol. 2000, 164, 549-553.

93. Mookherjee, N.; Hancock, R.E. Cationic host defense peptides: Innate immune regulatory peptides as a novel approach for treating infections. Cell Mol. Life Sci. 2007, 64, 922-933.

94. Varoga, D.; Pufe, T.; Harder, J.; Schroder, J.M.; Mentlein, R.; Meyer-Hoffert, U.; Goldring, M.B.; Tillmann, B.; Hassenpflug, J.; Paulsen, F. Human beta-defensin 3 mediates tissue remodeling processes in articular cartilage by increasing levels of metalloproteinases and reducing levels of their endogenous inhibitors. Arthritis Rheum. 2005, 52, 1736-1745.

95. Howell, M.D.; Novak, N.; Bieber, T.; Pastore, S.; Girolomoni, G.; Boguniewicz, M.; Streib, J.; Wong, C.; Gallo, R.L.; Leung, D.Y. Interleukin-10 downregulates anti-microbial peptide expression in atopic dermatitis. J. Invest. Dermatol. 2005, 125, 738-745.

96. Lillard, J.W., Jr.; Boyaka, P.N.; Chertov, O.; Oppenheim, J.J.; McGhee, J.R. Mechanisms for induction of acquired host immunity by neutrophil peptide defensins. Proc. Natl. Acad. Sci. USA 1999, 96, 651-656.

97. Brogden, K.A.; Heidari, M.; Sacco, R.E.; Palmquist, D.; Guthmiller, J.M.; Johnson, G.K.; Jia, H.P.; Tack, B.F.; McCray, P.B. Defensin-induced adaptive immunity in mice and its potential in preventing periodontal disease. Oral Microbiol. Immunol. 2003, 18, 95-99.

98. Mader, J.S.; Ewen, C.; Hancock, R.E.; Bleackley, R.C. The human cathelicidin, 11-37, induces granzyme-mediated apoptosis in regulatory t cells. J. Immunother. 2011, 34, 229-235.

99. Sorensen, O.E.; Cowland, J.B.; Theilgaard-Monch, K.; Liu, L.; Ganz, T.; Borregaard, N. Wound healing and expression of antimicrobial peptides/polypeptides in human keratinocytes, a consequence of common growth factors. J. Immunol. 2003, 170, 5583-5589.

100. Dorschner, R.A.; Pestonjamasp, V.K.; Tamakuwala, S.; Ohtake, T.; Rudisill, J.; Nizet, V.; Agerberth, B.; Gudmundsson, G.H.; Gallo, R.L. Cutaneous injury induces the release of cathelicidin anti-microbial peptides active against group a streptococcus. J. Invest. Dermatol. 2001, 117, 91-97.

101. Hirsch, T.; Spielmann, M.; Zuhaili, B.; Fossum, M.; Metzig, M.; Koehler, T.; Steinau, H.U.; Yao, F.; Onderdonk, A.B.; Steinstraesser, L.; et al. Human beta-defensin-3 promotes wound healing in infected diabetic wounds. J. Gene Med. 2009, 11, 220-228.

102. Koczulla, R.; von Degenfeld, G.; Kupatt, C.; Krotz, F.; Zahler, S.; Gloe, T.; Issbrucker, K.; Unterberger, P.; Zaiou, M.; Lebherz, C.; et al. An angiogenic role for the human peptide antibiotic 11-37/hcap-18. J. Clin. Invest. 2003, 111, 1665-1672.

103. Brandenburg, L.O.; Jansen, S.; Wruck, C.J.; Lucius, R.; Pufe, T. Antimicrobial peptide rcramp induced glial cell activation through p2y receptor signalling pathways. Mol. Immunol. 2010, 47, 1905-1913.

104. Lee, H.S.; Park, C.B.; Kim, J.M.; Jang, S.A.; Park, I.Y.; Kim, M.S.; Cho, J.H.; Kim, S.C. Mechanism of anticancer activity of buforin iib, a histone h2a-derived peptide. Cancer Lett. 2008, 271, 47-55. 
105. Falagas, M.E.; Kasiakou, S.K. Colistin: The revival of polymyxins for the management of multidrug-resistant gram-negative bacterial infections. Clin. Infect. Dis. 2005, 40, 1333-1341.

106. Prenner, E.J.; Lewis, R.N.; McElhaney, R.N. The interaction of the antimicrobial peptide gramicidin s with lipid bilayer model and biological membranes. Biochim. Biophys. Acta 1999, 1462, 201-221.

107. Steenbergen, J.N.; Alder, J.; Thorne, G.M.; Tally, F.P. Daptomycin: A lipopeptide antibiotic for the treatment of serious gram-positive infections. J. Antimicrob. Chemother. 2005, 55, 283-288.

108. Cheigh, C.I.; Pyun, Y.R. Nisin biosynthesis and its properties. Biotechnol. Lett. 2005, 27, $1641-1648$.

109. Smith, L.; Lu, S.E. Medical claims and current applications of the potent echinocandin antifungals. Recent Pat. Antiinfect. Drug Discov. 2010, 5, 58-63.

110. Joly, V.; Jidar, K.; Tatay, M.; Yeni, P. Enfuvirtide: From basic investigations to current clinical use. Expert Opin. Pharmacother. 2010, 11, 2701-2713.

111. McInturff, J.E.; Wang, S.J.; Machleidt, T.; Lin, T.R.; Oren, A.; Hertz, C.J.; Krutzik, S.R.; Hart, S.; Zeh, K.; Anderson, D.H.; et al. Granulysin-derived peptides demonstrate antimicrobial and anti-inflammatory effects against propionibacterium acnes. J. Invest. Dermatol. 2005, 125, 256-263.

112. Kazemzadeh-Narbat, M.; Kindrachuk, J.; Duan, K.; Jenssen, H.; Hancock, R.E.; Wang, R. Antimicrobial peptides on calcium phosphate-coated titanium for the prevention of implant-associated infections. Biomaterials 2010, 31, 9519-9526.

113. Papo, N.; Shai, Y. Effect of drastic sequence alteration and d-amino acid incorporation on the membrane binding behavior of lytic peptides. Biochemistry 2004, 43, 6393-6403.

114. Svenson, J.; Stensen, W.; Brandsdal, B.O.; Haug, B.E.; Monrad, J.; Svendsen, J.S. Antimicrobial peptides with stability toward tryptic degradation. Biochemistry 2008, 47, 3777-3788.

115. Scott, R.W.; DeGrado, W.F.; Tew, G.N. De novo designed synthetic mimics of antimicrobial peptides. Curr. Opin. Biotechnol. 2008, 19, 620-627.

116. Tew, G.N.; Scott, R.W.; Klein, M.L.; Degrado, W.F. De novo design of antimicrobial polymers, foldamers, and small molecules: From discovery to practical applications. Account. Chem. Res. 2010, 43, 30-39.

117. Ostergaard, C.; Sandvang, D.; Frimodt-Moller, N.; Kristensen, H.H. High cerebrospinal fluid (csf) penetration and potent bactericidal activity in csf of nz2114, a novel plectasin variant, during experimental pneumococcal meningitis. Antimicrob. Agents Chemother. 2009, 53, $1581-1585$.

118. Xiong, Y.Q.; Hady, W.A.; Deslandes, A.; Rey, A.; Fraisse, L.; Kristensen, H.H.; Yeaman, M.R.; Bayer, A.S. Efficacy of nz2114, a novel plectasin-derived cationic antimicrobial peptide antibiotic, in experimental endocarditis due to methicillin-resistant staphylococcus aureus. Antimicrob. Agents Chemother. 2011, 55, 5325-5330.

119. Ghosh, J.K.; Shaool, D.; Guillaud, P.; Ciceron, L.; Mazier, D.; Kustanovich, I.; Shai, Y.; Mor, A. Selective cytotoxicity of dermaseptin $\mathrm{s} 3$ toward intraerythrocytic plasmodium falciparum and the underlying molecular basis. J. Biol. Chem. 1997, 272, 31609-31616. 
120. Porat, Y.; Marynka, K.; Tam, A.; Steinberg, D.; Mor, A. Acyl-substituted dermaseptin s4 derivatives with improved bactericidal properties, including on oral microflora. Antimicrob. Agents Chemother. 2006, 50, 4153-4160.

121. Nicolas, P.; El Amri, C. The dermaseptin superfamily: A gene-based combinatorial library of antimicrobial peptides. Biochim. Biophys. Acta 2009, 1788, 1537-1550.

122. van der Does, A.M.; Bogaards, S.J.; Ravensbergen, B.; Beekhuizen, H.; van Dissel, J.T.; Nibbering, P.H. Antimicrobial peptide hlf1-11 directs granulocyte-macrophage colonystimulating factor-driven monocyte differentiation toward macrophages with enhanced recognition and clearance of pathogens. Antimicrob. Agents Chemother. 2010, 54, 811-816.

123. Steinberg, D.A.; Hurst, M.A.; Fujii, C.A.; Kung, A.H.; Ho, J.F.; Cheng, F.C.; Loury, D.J.; Fiddes, J.C. Protegrin-1: A broad-spectrum, rapidly microbicidal peptide with in vivo activity. Antimicrob. Agents Chemother. 1997, 41, 1738-1742.

124. Koprivnjak, T.; Peschel, A. Bacterial resistance mechanisms against host defense peptides. Cell Mol. Life Sci. 2011, 68, 2243-2254.

125. Cirioni, O.; Silvestri, C.; Ghiselli, R.; Orlando, F.; Riva, A.; Mocchegiani, F.; Chiodi, L.; Castelletti, S.; Gabrielli, E.; Saba, V.; et al. Protective effects of the combination of alpha-helical antimicrobial peptides and rifampicin in three rat models of pseudomonas aeruginosa infection. J. Antimicrob. Chemother. 2008, 62, 1332-1338.

126. Pfeufer, N.Y.; Hofmann-Peiker, K.; Muhle, M.; Warnke, P.H.; Weigel, M.C.; Kleine, M. Bioactive coating of titanium surfaces with recombinant human beta-defensin-2 (rhubetad2) may prevent bacterial colonization in orthopaedic surgery. J. Bone Joint Surg. Am. 2011, 93, 840-846.

127. Steinstraesser, L.; Trust, G.; Rittig, A.; Hirsch, T.; Kesting, M.R.; Steinau, H.U.; Jacobsen, F. Colistin-loaded silk membranes against wound infection with pseudomonas aeruginosa. Plast. Reconstr. Surg. 2011, 127, 1838-1846.

128. Gao, G.; Lange, D.; Hilpert, K.; Kindrachuk, J.; Zou, Y.; Cheng, J.T.; Kazemzadeh-Narbat, M.; Yu, K.; Wang, R.; Straus, S.K.; et al. The biocompatibility and biofilm resistance of implant coatings based on hydrophilic polymer brushes conjugated with antimicrobial peptides. Biomaterials 2011, 32, 3899-3909.

129. Haynie, D.T.; Zhang, L.; Rudra, J.S.; Zhao, W.; Zhong, Y.; Palath, N. Polypeptide multilayer films. Biomacromolecules 2005, 6, 2895-2913.

130. Cole, N.; Hume, E.B.; Vijay, A.K.; Sankaridurg, P.; Kumar, N.; Willcox, M.D. In vivo performance of melimine as an antimicrobial coating for contact lenses in models of clare and clpu. Invest. Ophthalmol. Vis. Sci. 2010, 51, 390-395.

131. Zhang, L.T.; Yao, Y.M.; Lu, J.Q.; Yan, X.J.; Yu, Y.; Sheng, Z.Y. Recombinant bactericidal/permeability-increasing protein inhibits endotoxin-induced high-mobility group box 1 protein gene expression in sepsis. Shock 2008, 29, 278-284.

132. Travis, S.; Yap, L.M.; Hawkey, C.; Warren, B.; Lazarov, M.; Fong, T.; Tesi, R.J. Rdp58 is a novel and potentially effective oral therapy for ulcerative colitis. Inflamm. Bowel. Dis. 2005, 11, $713-719$. 
133. Chavakis, T.; Cines, D.B.; Rhee, J.S.; Liang, O.D.; Schubert, U.; Hammes, H.P.; Higazi, A.A.; Nawroth, P.P.; Preissner, K.T.; Bdeir, K. Regulation of neovascularization by human neutrophil peptides (alpha-defensins): A link between inflammation and angiogenesis. FASEB J. 2004, 18, 1306-1308.

134. Lee, P.H.; Rudisill, J.A.; Lin, K.H.; Zhang, L.; Harris, S.M.; Falla, T.J.; Gallo, R.L. Hb-107, a nonbacteriostatic fragment of the antimicrobial peptide cecropin $b$, accelerates murine wound repair. Wound Repair Regen. 2004, 12, 351-358.

(C) 2012 by the authors; licensee MDPI, Basel, Switzerland. This article is an open access article distributed under the terms and conditions of the Creative Commons Attribution license (http://creativecommons.org/licenses/by/3.0/). 